\title{
Course of membranous nephropathy during multiple gestations
}

\author{
Abhilash Koratala, ${ }^{1}$ Dara N Wakefield, ${ }^{2}$ Ananthalaxmi Vangapalli, ${ }^{3}$ Abutaleb A Ejaz ${ }^{1}$
}

'Department of Nephrology, University of Florida College of Medicine, Gainesville, Florida, USA

${ }^{2}$ Department of Pathology and Immunology, University of Florida College of Medicine, Gainesville, Florida, USA ${ }^{3}$ Hebei Medical University, Shijiazhuang City, China

\section{Correspondence to Dr Abhilash Koratala, akoratsla@ufl.edu}

Accepted 12 November 2016

CrossMark

To cite: Koratala $\mathrm{A}$, Wakefield DN, Vangapalli A, et al. BMJ Case Rep Published online: [please include Day Month Year] doi:10.1136/bcr-2016218363

\section{DESCRIPTION}

The physiological adaptations in pregnancy can unmask underlying occult proteinuric renal disease. However, the effect of multiple pregnancies on the course of the disease is variable. We report the clinical course of a case of idiopathic membranous nephropathy through multiple pregnancies.

A 25-year-old Hispanic woman was referred to our institution for worsening generalised swelling of the body, uncontrolled hypertension and $21 \mathrm{~g} /$ day of proteinuria at 34 weeks' gestation during her third pregnancy. There were no stigmata suggestive of HELLP (Hemolysis, Elevated Liver enzymes, Low Platelet count) syndrome. She was previously seen at our institution 5 years ago during her 1st pregnancy when $13 \mathrm{~g} /$ day of proteinuria was recorded at 25 weeks of gestation. At that time, she was treated with oral steroids and delivery was induced at 35 weeks due to intrauterine growth restriction. Placental biopsy revealed focal, tightly adherent blood clot, consistent with possible abruption. Renal biopsy performed in the postpartum period was consistent with membranous nephropathy (figure 1).

She was treated with ACE inhibitors (ACEI) and at 3-month follow-up, she was asymptomatic, without oedema and urine protein-creatinine ratio (UPCR) had decreased to $7 \mathrm{~g} / \mathrm{g}$. She was lost to follow-up for 5 years until this recent admission. In the interim, she apparently had a second successful pregnancy but no data was available. During current pregnancy, delivery was induced at 34 weeks and the placental biopsy showed that it was critically small for gestational age and had focal intervillous fibrin deposition together with

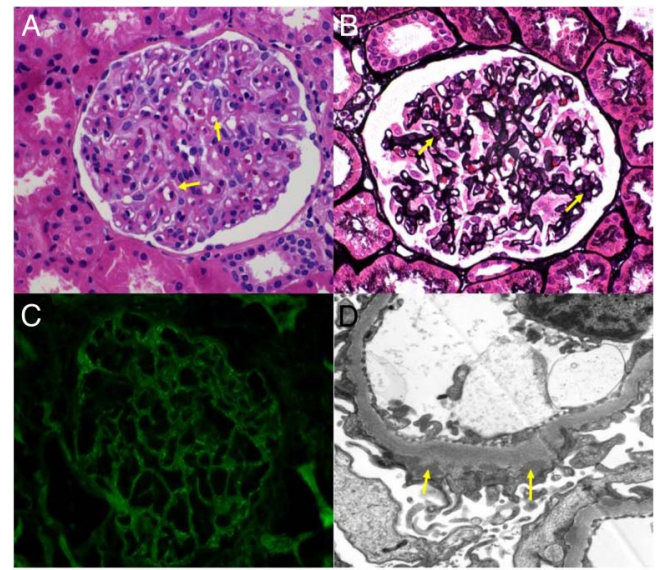

Figure 1 Renal biopsy consistent with membranous nephropathy (A) H\&E section showing thickened capillary loops (arrows); (B) silver stain showing thickened basement membranes (arrows); (C) immunofluorescence for IgG showing fine granular positivity; and (D) electron microscopy showing subepithelial deposits (arrows).

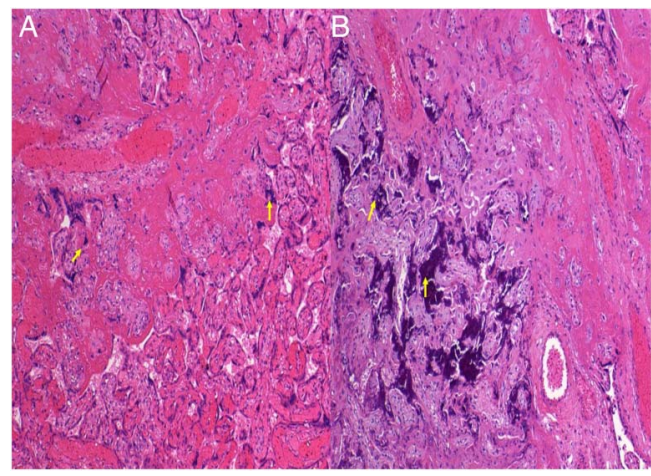

Figure 2 Placental biopsy showing (A) focal intervillous fibrin deposition (arrows) and (B) focal calcifications (arrows) in the areas of significant ischaemia.

focal calcifications in the areas of more significant ischaemia (figure 2). Serology for antinuclear antibody, anti-double-stranded DNA, antiphospholipid antibody, viral hepatitis and rapid plasma regain were negative. Serum complements were within normal limits. During both the pregnancies, she had hypertension with average blood pressures in the range of $140-150 / 80-90 \mathrm{~mm} \mathrm{Hg}$, which is higher than expected for a normal pregnancy but within acceptable range for patients with preexisting chronic hypertension. At 1-month postpartum, UPCR was $1.8 \mathrm{~g} / \mathrm{g}$, without any treatment. Interestingly, her serum creatinine ranged between 0.6 and $0.9 \mathrm{mg} / \mathrm{dL}$ during this 5 -year period. The patient was once again lost to follow-up.

\section{Learning points}

- Although there is physiological increase in proteinuria during pregnancy, the presence of nephrotic range proteinuria with or without hypertension in any trimester is always pathological and may be associated with underlying renal disease and a poor prognosis. ${ }^{1}$

- Our case supports that spontaneous remission of membranous nephropathy can occur despite physiological changes associated with pregnancy and the natural course of the disease probably follows that of non-pregnant individuals.

- Pregnant patients with high-grade proteinuria are at increased risk for placentofetal complications including intrauterine growth restriction, preterm delivery and fetal demise as evidenced by our case and existing literature. ${ }^{23}$ Also, our patient had hypertension, which is an independent risk factor for such complications. 
Contributors AK and AV have prepared the initial draft. DNW has procured the images and AAE has critically revised the manuscript for important intellectual content. All the authors approved the manuscript for final submission.

Competing interests None declared.

Patient consent Obtained.

Provenance and peer review Not commissioned; externally peer reviewed.

\section{REFERENCES}

1 Katzir Z, Rotmensch S, Boaz M, et al. Pregnancy in membranous glomerulonephritis —course, treatment and outcome. Clin Nephrol 2004;61:59-62.

2 Aoshima Y, lyoda M, Nakazawa A, et al. Membranous nephropathy that first presented in pregnancy. Intern Med 2013;52:1949-52.

3 Ope-Adenuga S, Moretti M, Lakhi N. Management of membranous glomerulonephritis in pregnancy: a multidisciplinary challenge. Case Rep Obstet Gynecol 2015;2015:839376.

Copyright 2016 BMJ Publishing Group. All rights reserved. For permission to reuse any of this content visit http://group.bmj.com/group/rights-licensing/permissions.

BMJ Case Report Fellows may re-use this article for personal use and teaching without any further permission.

Become a Fellow of BMJ Case Reports today and you can:

- Submit as many cases as you like

- Enjoy fast sympathetic peer review and rapid publication of accepted articles

- Access all the published articles

- Re-use any of the published material for personal use and teaching without further permission

For information on Institutional Fellowships contact consortiasales@bmjgroup.com

Visit casereports.bmj.com for more articles like this and to become a Fellow 